Emmanuel Innocents Edoun (South Africa), Dikgang Motsepe (South Africa)

\title{
Critical assessment of Highly Indebted Poor Countries (HIPIC) Initiative in Africa and the Implication of the New Partnership for Africa's Development (NEPAD) (2001-2016): a theoretical perspective
}

\begin{abstract}
Many African countries have been struggling to achieve sustainable economics in order to contribute in putting Africa in the path for socio-economic development. This is partly due to the burden of debt that hangs over many African countries that borrowed funds from multilateral partners irresponsibly. As a result of this, the International Monetary Fund (IMF) and the World Bank put in place in 1996 a strategy to provide debt relief to countries that were struggling to repay their debts. This debt relief initiative was reviewed in 1999 to provide adequate results. This paper is, therefore, a critical assessment of HIPIC and the implication of NEPAD from 2001 to date.
\end{abstract}

Keywords: HIPIC, NEPAD, IMF, World Bank, socio-economic development.

JEL Classification: H62, H63.

\section{Introduction}

The twenty-second meeting of the Committee of Experts of the Conference of African Ministers of Finance in May 2003, highlighted that in many African countries, domestic debt burden is causing severe problems in terms of fiscal sustainability, high interest rates and crowding-out of private sector investment. The domestic debt burden further hampers the development of the private sector, as firms do not receive prompt payment for providing goods and services. It was underscored by some participants that if the role of domestic debt is ignored, the magnitude of the fiscal effort that poor countries will have to make in the post-HIPC era will be underestimated. The Committee agreed that domestic and external debt is entirely different in nature and some experts shared successful country experiences on tackling domestic debt by working closely with donors ${ }^{1}$.

Africa can never develop with the high magnitude of debt it still has to repay. Firstly, it lacks the capacity and resources, and secondly the imposed conditionalities that prevail, which has made it difficult for countries to take ownership of their own development. The World Bank and International Monetary Fund (IMF) need to accept that over 20 years of structural adjustment policies, the continent is still worse off. They have failed with alleviating poverty, promoting development and generating economic growth. The current sluggish progress of

(C) Emmanuel Innocents Edoun, Dikgang Motsepe, 2016.

Emmanuel Innocents Edoun, Tshwane University of Technology, Pretoria, South Africa.

Dikgang Motsepe, The University of the Witwatersrand Johannesburg, South Africa.

${ }^{1}$ The twenty-second meeting of the Committee of Experts of the Conference of African Ministers of Finance, Planning and Economic Development was held in the United Nations Conference Centre, Addis Ababa, Ethiopia, May 29-31, 2003. the HIPC Initiative in responding to the debt burden countries face rests in the incorrect assumptions made, which are based on the structural adjustment policies.

The continent's debt crisis can be attributed to number of external factors, i.e., oil price shocks of the 1970s, the expansion of the Eurodollar, the rise in public expenditure by African governments following the rise in commodity prices in the early 1970s, the recession in industrial countries and the subsequent fall in commodity prices, the rise in world interest rates, and the inappropriate economic policies forced by the World Bank and IMF which became an important component of flows to Africa [1]. The component of Africa's debt can be classified as follows - multilateral, bilateral, and private creditors, with long-term debt being the most significant component of the debt burden (refer to annex statistical table for more details). In 1996, the Heavily Indebted Poor Countries (HIPC) Initiatives was created as the first comprehensive debt relief framework that included commercial institutions, government creditors, the World Bank and IMF. This paper seeks to provide recommendations to addressing the debt issue within the interest of the African Union framework and its related organs such as the New Partnership for Africa's Development (NEPAD).

\section{The HIPC Initiative}

"The HIPC Initiative is to provide debt cancellation (rather than palliatives such as debt rescheduling, and interest rate reduction) as the main means to ease the debt burden of the poorest and most indebted countries. It also radically included debt cancellation owed to multilateral institutions such as the World Bank, the International Monetary Fund, the African Development Bank and the InterAmerican Development Bank [2]”. 
The HIPC Initiative promised higher debt cancellation compared to the traditional debt relief mechanisms from the Paris Club creditors (who promised to cancel $90 \%$ of their foreign loans), multilateral institutions and other cooperative creditors. The Initiative is an approach that required the participation of all creditors - bilateral, multilateral, and commercial (Paris Club creditors, multilateral institutions, regional development banks, cooperative non-Paris Club creditors and cooperative commercial creditors). The Initiative aims to make debt service burdens manageable through a mixture of sound policies (linking debt relief to poverty reduction strategies), debt relief and new aid flows [3].

To be eligible for HPIC assistance, countries were compelled to meet the following criteria:

- face an unsustainable debt burden, beyond available debt relief mechanism;

- establish a track record of reform and sound policies through IMF and World Bank supported programs.

Currently there are 42 countries that are eligible for the assistance, with Kenya, Yeman, Angola and Vietnam having reached a sustainable level debt. All countries requesting HIPC assistance were supposed to have adopted a PRSP by decision point (first phase) and have made progress in implementing the strategy for at least one year by completion point (second phase). During this time, continued to receive traditional concessional assistance from all the relevant donors and multilateral institutions, as well as debt relief from bilateral creditors - Paris Club.

\section{Progress made and analysis of HIPC}

A Jubilee Research report, undertaken by Romilly Greenhill (2002), provided a good summary of the World Bank and IMF's HIPC initiative since its inception in 1996. The findings were as follows:

- Of the 19 countries originally expected to reach Completion Point by the end of 2002, at least 11 or $60 \%$ will fail.

- The number of countries expected to face unsustainable debt burdens at Completion Point was 13.3 more than expected in April 2002.

- 13 out of the 20 'interim' period countries have gone off-track with their IMF programs at some point, therefore, delaying debt cancellation and denying them interim debt service relief.

- According to the narrow definition of the World Bank and IMF, HIPC only appears to be working for 10 countries out of the 42 included within the initiative.

- The World Bank and IMF have considered, but rejected, alternative proposals for debt relief on the grounds that they are 'unaffordable' and will create 'moral hazard' - both changes rejected by Jubilee Research.

The reports released by World Bank and IMF in 2002 which confirmed the predictions from the Jubilee Research, that HIPC countries would never reach the export growth targets set in the Decision Point documents. The reason being that the higher exports will mean lower debt cancellation needed a tool used by the World Bank and IMF [4].

A joint report by NGOs [5] (2002) gave a critical analysis of the enhanced HIPC Initiative with reference to the positive pictures painted by the World Bank and the IMF. Their analysis was as follows:

- Out of the 20 HIPC countries which reached the Decision Point, 4 countries (Mali, Niger, Serria Leone and Zambia) were, therefore, expected to have annual debt service payments due in 20032005 which was virtually actually be higher than their annual debt service paid in 1998-2000.

- 5 countries were expected to pay almost as much in debt service payments as before HIPC (Ethiopia, Guinea-Bissau, Honduras, Nicaragua and Uganda).

- In 6 countries, an annual debt serviced was reduced by a modest $\$ 15$ million in 2003-2005.

- The medium to longer term projections on debt servicing was drastically high and remained so up till today - Senegal's debt service jumped by $61 \%$ in 2004 , Nicaragua's rose by $60 \%$ in 2002 , Mauritania's rose by $46 \%$ in 2007, and Honduras by $93 \%$ in 2002 .

- Over half of the HIPC countries are spending more than $15 \%$ of their government revenue on debt servicing.

In greater context, debt relief is implemented over a long period of 20-30 years depending on the relief method chosen and that the relief is only delivered with strict conditions that need to be met. The collapse in commodity price has left countries overshooting the defined threshold of debt sustainability. Uganda, for example, has recorded debts of over $200 \%$ of the debt-to-export ratio, exceeding its debt sustainability after reaching Completion Point. The World Bank and IMF projections of economic growth, investment rates and capital inflows have been overoptimistic. And the use of such unrealistic forecasts was bound to lead to unrealistic debt sustainability analysis and countries overshooting their sustainability threshold. Oxfam noted that the Bank's wildly optimistic growth projections are undermining the effectiveness of HIPC relief, since the amount of debt relief provided is directly linked to anticipated revenues. 
HIPC countries are vulnerable to external shocks with particular reference to exports - price shocks, poor market access to developing countries, and climate conditions. The current export criterion of the NPV of debt-to-exports for debt sustainability analysis will, therefore, be an unreliable measure to calculate future debt due to the volatile export variables. It is totally unrealistic for the World Bank and IMF to directly link the amount of debt relief provided to anticipated export revenues given that HIPC countries are not market makers but takers. To add, the unfair trading level the global system has created with regards to trade barriers and restricted market access to developed countries. They have clearly failed to take the economic positions of these countries.

One important observation to be made from HIPC is that despite its inception, African countries still struggle with heavy debt payments. The Finance Minister of Tanzania address to parliament in 2001, outlined that while the program provided relief, the country still owed billions and that under the current conditions, it will take the country a long time to pay off its debt. Tanzania's situation is identical to many Sub-Saharan African countries that have qualified for debt relief $-\mathrm{a}$ significant lowering of debt initially followed by rising obligations as new money is borrowed to service old debt and finance basic development programs (health and education), refer to Table 1. In 1998, the sub-Saharan Africa's annual debt service payments amounted to $\$ 15.2$ billion or $15 \%$ of exports, with the total debt standing at \$231 billion in 2003.

Table 1. Debt servicing of 17 African countries estimates, \$ millions

\begin{tabular}{|l|c|c|c|c|}
\hline & 2000 & 2005 & 2010 & 2015 \\
\hline Benin & 62.5 & 36.9 & 43.9 & 72.8 \\
\hline Burkino Faso & 33.8 & 41.5 & 54.7 & 83.2 \\
\hline Cameroon & 312 & 347 & 375 & n.a. \\
\hline Gambia & 19.6 & 9.8 & 18.7 & 23.4 \\
\hline Guinea & 140 & 88 & 96 & 111 \\
\hline Guinea-Bissau & 15 & 4 & 11 & n.a. \\
\hline Madagascar & 104.5 & 81.6 & 119.5 & 156.2 \\
\hline Malawi & n.a & 47.1 & 55 & 85.9 \\
\hline Mali & 88 & 66 & 76 & 125 \\
\hline Mauritania & 87.4 & 43.3 & n.a. & 47.3 \\
\hline Mozambique & 50 & 60 & 97 & 98 \\
\hline Niger & 93.5 & 29 & 26.4 & 35.4 \\
\hline Rwanda & 39.6 & 11.1 & 14.7 & 27.7 \\
\hline So Tome \& & n.a. & 1 & 3.3 & 2.8 \\
\hline Principe & 184.9 & 136.1 & n.a. & n.a. \\
\hline Senegal & 153.8 & 158.2 & n.a. & 258 \\
\hline Tanzania & 169 & 202 & 135 & 109 \\
\hline Zambia & & & & \\
\hline
\end{tabular}

Source: World Bank and IMF.
The HIPC initiative has been condemned by NGOs (Jubilee Research) for failing to meet its stated objectives, for being designed in the interests of creditors and for imposing structural adjustment conditions to HIPC countries. The definition of debt sustainability is "narrow and does not deal with issues of domestic debt, which are important for fiscal sustainability, nor does it measure the adequacy of public resources to address priority development programs after debt services has been made [13]".

Forcing countries to follow the IMF Poverty Reduction and Growth Facility (PRGF) programs in order to gain relief renders the process flowed and doomed for failure. The HIPC initiative imposes old structural adjustment policies with new names such policies bear no positive results to the African continent. Under the Enhanced HIPC Initiative, from the 22 countries of which 18 are from Africa that reached their decision point, only 2 African countries (Uganda \& Mozambique) finished the entire debt relief process and reached their completion points [6].

Table 2. African countries that have qualified for are eligible or potentially eligible and may wish to receive HIPC initiative assistance from

\section{March 2016}

\begin{tabular}{|c|c|c|c|c|}
\hline \multicolumn{5}{|c|}{ Post-completion-point countries (36) } \\
\hline 1. & Benin & The Gambia & 3. & Mauritania \\
\hline 4. & Burkina Faso & 5. Ethiopia & 6. & Mozambique \\
\hline 7. & Burundi & Ghana & 9. & Niger \\
\hline 10. & Cameroon & 11. Guinea & 12. & Rwanda \\
\hline 13. & $\begin{array}{l}\text { Central African } \\
\text { Republic }\end{array}$ & 14. Guinea Bissau & 15. & $\begin{array}{l}\text { São Tomé \& } \\
\text { Príncipe }\end{array}$ \\
\hline 16. & Tchad & 17. Liberia & 18. & Senegal \\
\hline 19. & Comoros & 20. Madagascar & 21. & Sierra Leone \\
\hline 22. & $\begin{array}{l}\text { Republic of } \\
\text { Congo }\end{array}$ & 23. Malawi & 24. & Tanzania \\
\hline 25. & $\begin{array}{l}\text { Democratic } \\
\text { Republic of } \\
\text { Congo }\end{array}$ & 26. Mali & 27. & Togo \\
\hline & Cote d'Ivoire & 29. Mauritania & 30. & 30- Uganda \\
\hline & & & 31. & Zambia \\
\hline \multicolumn{5}{|c|}{ Pre-decision-point countries (3) } \\
\hline & 1- $\quad$ Eriterea & 2- $\quad$ Somalia & & 3- $\quad$ Soudan \\
\hline
\end{tabular}

Source: www.imf.org.

The combined, HIPC and Multilateral Debt Relief Initiative have cancelled $\$ 97$ billion worth of debt, majority from the sub-Saharan African countries [17]. The total debt relief under both schemes combined for all 39 eligible countries is estimated at $\$ 116$ billion [17].

The positives from the debt cancellations as highlighted by the One included countries agreeing to channel their debt savings to poverty reduction activities, i.e., Tanzania used its debt savings to 
abolish primary school fees in 2002, Mozambique used its debt service savings to vaccinate children against tetanus, whooping cough and diphtheria, as well as to install electricity in schools and to build new ones, and Cameroon used its debt savings to launch a national HIV/AIDS plan for education, testing and prevention, including of mother-to-child transmission [17].

\section{Recurrent challenges}

In its publication on Debt Relief under the Heavily Indebted Poor Countries (HIPC) Initiative April 8, 2016, the IMF argued that, in Africa, countries such as Eritrea, Somalia and Sudan that fall under the pre-decision point are under similar challenges that also include the issue of peace and security. Eligible countries are also compelled to get full debt relief from creditors in order to allow African governments to pursue socio-economic development through structuring projects that require large amount of funds. However, the IMF argued that it will continue to address issues related to participation in the HIPC Initiative during its regular consultations and other missions to creditor countries [15].

It should be noted that not all poor countries have benefited from debt cancellation. The One Organization states that a number of countries excluded from the original HIPC deal because of their good work in managing their debts, despite spending significant amounts servicing their debt [17]. The One Organization further states that in 2013, Lesotho spent \$40 million paying its external creditors, Kenya spent $\$ 620$ million, which is equal to $20 \%$ of the aid it received the same year [17].

The study undertaken by the One Organization highlights that a significant number of countries that benefited from the first rounds of debt cancellation are now re-accumulating debts due to the increased supply of credit to these countries by new creditors [17]. The study further states that foreign loans to low-income countries trebled between 2008 and 2013, and that the World Bank and IMF estimate that over half of the countries that were included in HIPC are now at risk of returning to unsustainable debt levels, including countries such as such as Ethiopia, Mozambique and Niger, whose foreign debt payments are higher than they were before debt relief [17]. Sambira (2015) states that 12 countries in sub-Saharan Africa have issued foreign bonds to the total value of $\$ 15$ billion between the said period.

Sulaiman (2014) supports this by indicating the increased danger of African governments seeking to replace declining foreign aid to fund infrastructure projects by taking up concessional funds from multilateral institutions and more expensive commercial bank loans and bilateral financing from lenders like China and Brazil, and by issuing Eurobonds. Sulaiman (2014) provides the evidence that Ghana became the first African beneficiary of debt relief to access the international capital markets, by issuing a $\$ 750$ million 10 -year Eurobond in 2007, and this was followed by Senegal, Nigeria, Zambia and Rwanda.

This observation will need to be monitored to ensure that countries do not revert to their unsustainable debt levels.

\section{NEPAD Initiative}

The New Partnership for Africa's Development has aligned debt reduction to complement the required external resources in the short to medium term to fill the required resource gap. NEPAD seeks the extension of debt relief beyond its current levels based on debt sustainability, which require debt service payments amounting to a significant portion of the resource gap. The long-term objective of NEPAD is to link debt relief to costed poverty reduction programs. In the interim, debt service ceilings should be fixed as a percentage of fiscal revenue, with different ceilings for international development assistance (IDA) and non-IDA countries. Further concessional resources will be negotiated by the leadership of NEPAD with creditor countries, via debt relief and ODA. The debt initiative will require agreed poverty reduction strategies, debt strategies and participation in the Economic Governance Initiative to ensure that countries are able to absorb the extra resource. In addition to the interim debt strategy, the leadership of NEPAD has established a forum in which African countries share experience and mobilize for the improvement of debt relief strategies [7].

\section{NEPAD's observations of the HIPC Initiative [8]}

(a) The HIPC initiative is not a permanent structure and is expected to come to an end in 2004 (with the possibility of an extension as written into the sunset clause).

(b) Substantial progress has been made since the adoption of the Enhanced HIPC Initiative, i.e., finalization of national PRSPs and the development of the NEPAD initiative, which allows for an enhanced partnership in addressing resource constraints in national development efforts.

(c) A number of problems have been observed in the enhanced HIPC program. These are:

- The process through which the HIPC evolved was not participatory. Therefore, it could be said to be donor driven. 
- The basis for determining the amount of relief to be granted is not open and, hence, nonparticipatory.

- The amount of relief granted is not related to the achievement of any specific anti-poverty program of target for the beneficiary economy.

- It is not comprehensive enough, and further resources are required to assist post-conflict countries.

- It does not respect the principle of partnership, which is the guiding philosophy of NEPAD.

(d) As some countries have progressed under the HIPC initiative, it has become apparent that the problems pertaining to their domestic debt burden have the potential of undermining the benefits of the HIPC initiative.

\section{Proposed work program}

The NEPAD proposed program has reviewed the current state-of-play of existing initiatives by proposing a longer-term and enhanced partnership to advance the development-orientation of debt relief in order to ensure their compatibility with the aims and aspirations of NEPAD. To note, NEPAD is not seeking relief for debt sustainability but for development sustainability. Towards this end, the following activities were proposed under the NEPAD Initiative:

(a) Articulating through research, the position of African countries on existing relief facilities.

(b) Evolve a framework for a valid assessment of the real financing needs towards effective poverty alleviation.

(c) Suggest institutional reforms and strategy for promoting broad-based participation in and contribution to national poverty eradication efforts, such as the role of the private sector in the financing of poverty alleviation programs.

\section{Proposals in dealing with debt relief}

The current assumption of the Debt Relief Initiative is that debtor countries are solely responsible for the crisis due to the lack of proper debt management, corruption and other unforeseen economic uncertainties. The debtor countries have been largely affected by external factors which has intensified the debt crisis, i.e., unfair global trade practices by developed countries with regards to market access and trade rules, declining terms of trade, natural disasters, inappropriate policy advice by the World Bank and IMF, etc. The HIPC initiative, as mentioned in the AFRODAD (Issues Papers No. 1/2002), is meant to protect the interests of creditors and the international financial system rather than that of debtor countries. They further state, the one major reason for the lack political will to resolve the debt crisis is that creditors see the protection of international financial systems as a basis of decision making.

\section{Partnership for African Recovery Program (MAP) debt relief initiative ${ }^{2}$}

The initiative provides a holistic approach in dealing with Africa's debt crisis by in-cooperating all the initiatives put forward in this paper. The approach is centralized towards poverty alleviation and human development which are critical to solving the continent's under development. Debt relief is one of the measures to be taken to freeing country resources to address poverty. Debt relief, concessional flows, private capital flows, and enhanced revenue generation through economic growth are all complementary means of mobilising resources that must be pursued simultaneously.

The MAP Debt Relief Initiative provides the following guiding principles in addressing the issue [11].

- African countries should not seek debt reduction on the basis of debt sustainability alone, but on the basis to free up domestic resources for poverty reduction and development purposes.

- The Initiative is based on the principle that a country facing high poverty levels complemented with limited access to private capital flows should be considered for debt relief beyond the current provisions. Such countries would demonstrate their commitment to poverty alleviation, principles of good government, sound economic management and enhanced mobilization of domestic resources towards poverty alleviation programs.

- Engagement between Africa and creditor governments, on a realistic African debt reduction strategy that will enhance the relationship between the parties that should strengthen the commitment of concessional resources to the continent.

- The Initiative will take into account the existing debt relief mechanisms and adopt an incremental approach to securing resources for poverty alleviation and development through debt relief known as the two-stage approach. Therefore, the mechanism will supplement the existing initiatives, i.e., HIPC Initiative and Paris Club.

The MAP Initiatives looks into the establishment of a forum in which African countries can share experiences of PRSP/HIPC process and develop reform positions. The UNECA's proposed PRSP Learning Group as recommended for this function.

\footnotetext{
${ }^{2}$ The Initiative in-cooperates both the MAP and OMEGA Action Plan that merged as the New African Initiative in 2001.
} 
The forum will also look at engaging the World Bank and IMF on issues of streamlining the HIPC process and so on. It will address issues such as the graduation of Decision to Completion Points, the process required to develop PRSPs, the question of country ownership, and interim financing [11].

Given the significant public debt service in poor countries, ceilings for debt service cost as a percentage of fiscal revenue would be established. Debt relief would be coordinated with government revenue projections and would include cancellation and various debt conversion options. Creditor countries would be urged not to substitute such relief by decreasing new ODA flows. In addition, committed African countries would set poverty targets and begin mobilizing resources to achieve their poverty reduction targets. MAP proposes that this level be set at $13 \%$ of fiscal revenue [11].

The MAP request for debt relief is based on the need to retain resources to foster development and reduce poverty. Therefore, the following instruments have been proposed - debt-for-equity swaps, debt-for-development swaps and the conversion of bilateral debt into marketable securities for the African countries. It is recommended that debt relief be undertaken in a manner that directly encourages foreign investment, development spending, the return of capital flight, and capital market access. Such instruments with regard to the debt swaps indicated, can be used to attract FDI and program funding, secure a strong position for creditor countries on the process, and provide for flexibility in meeting sustainable ratios on an annual basis should other forms of debt relief result in uncertainty of annual debt service payments [11].

\section{Response from the IMF and World Bank on debt cancellation}

"The HIPIC Initiative is a comprehensive approach in removing debt as a constraint in poor countries struggling against poverty. It sets the stage for determined countries, supported by the international community to overcome other constraints to overcome poverty [12]".

Up till today the World Bank and IMF have welcomed the intention of creditor governments to provide additional debt reduction beyond the HIPC Initiative, provided that the relief is not offset by reductions in aid flows. They further state that debt cancellation would require collective or concerted action by all creditors, and that total cancellation would seriously jeopardize the overall flow of financial support for the poorest countries. Their argument is based on the following: the importance of maintaining new flows of assistance if debt relief is to add to poverty reduction efforts, a decline of $10 \%$ in new flows would wipe out the benefits of HIPC debt relief; total debt cancellation would be offset by a cut of $20 \%$ in aid flows; and that creditor confidence to issue new loans and repayment of such loans would be low (therefore, affecting the debtor country's ability to seek funding). However, one can argue that debt cancellation will reduce the dependency of aid by many African countries and LDC [12].

Great emphasis is placed on HIPCs and other poor countries reliance on external support or financing for financing developmental needs, funding made by bilateral and multilateral agencies on concessional terms. The World Bank and IMF see that total cancellation could deter such funds and could also undermine the confidence of existing and potential investors to fund the developmental needs. Given the soft lending window of IDA finance and regional development banks (IDB, AfDB, AsDB), debt cancellation will cripple their ability to make future funding to poor countries. "Debt cancellation would also deplete the resources of the PRGF Trust and force closure of the facility". The IMF speculates that debt cancellation will harm its financial position and credibility, and that its gold reserves are a fundamental strength to its financial position. Therefore, it may not use or deplete reserves, as it will reduce its capacity to assist its members in crisis situations [17].

The way forward stated by the World Bank and IMF is for the international community to support the poverty reduction strategies of the low-income countries by opening their markets to their exports and increasing new concessional flows. The World Bank and IMF reaffirmed their commitment to complete the HIPC Initiative at the Ministerial Meeting in Dubai September 2003. They urged all bilateral creditors to join them in canceling out the $100 \%$ of their eligible claims. They asked for IFIs to review the methodology for calculating the amount of 'topping up debt' relief.

\section{Conclusion and recommendations}

Debt repayment has been a reverse of capital flows and has hindered government's social spending on basic health and education, their ability to fight the HIV/AIDS pandemic, and to generate growth and sustainable development - in a nut shell, Africa's debt crisis is a major bottleneck constraining the recovery and development of the continent.

The African position on debt should seek to extend debt relief beyond the current coverage. The African position should not look to replace the existing mechanism of HIPC, but enhance the process that seeks to link debt relief to poverty reduction and 
meeting of MDGs. Other areas that require further analysis will be the debt service ceiling (that should be fixed as a certain percentage of fiscal revenue), which is the long term objective of Africa's position. The initiative as stipulated in the NEPAD framework, which will require agreed poverty reduction strategies and debt strategies to ensure that countries are able to absorb the extra resources.

The recommendations and way forward as articulated in the NEPAD framework are as follows: 1) the heads of state of NEPAD will secure an agreement, negotiated with the international community, to provide further debt relief for countries participating in the NEPAD agenda and principles; 2) the leadership of NEPAD will establish a forum in which African countries may share experiences and mobilize for the improvement of debt relief strategies. And lastly, debt relief should be supported by increased market access to developed economies that would assist in the resource mobilization and revenue increase of countries to support the poverty reduction programs and achievement of MDGs.

Lastly, the is a need to increase the focus on responsible borrowing and lending and endorse the Principles on Responsible Sovereign Lending and Borrowing set by The United Nations Conference on Trade and Development, and ensure countries that benefited from the debt relief do not relapse.

\section{References}

1. Geda, A. (2001). Debt issues in Africa: Thinking beyond the HIPC initiative to solving structural problems, The Kenya Institute for Public Policy and Research and Addis Ababa University.

2. UNDP (2003). Research and Policy Analysis on debt relief and external financing for HIPC countries: linking the HIPC Initiative with the MDGs, Concept Note.

3. UNDP (2003). Initial Partial Draft Towards A Practice Note On The HIPC Initiative, Policy Note.

4. Greenhill, R. and Blackmore, S. (2002). Relief Works: African Proposal For Debt Cancellation And Why Debt Relief Works, A report from Jubilee Research at the New Economics foundation.

5. CAFOD, Oxfam, Christian Aid, EURODAD (2002). A Joint Submission To The World Bank And IMF Review Of HIPC And Debt Sustainability.

6. Colgan, A. (2001). Africa Action Position Paper, University of Pennsylvania, African Studies Center.

7. NEPAD (2001). Capital Flows Initiative.

8. NEPAD (2003). Resource Flows Initiative: Work Program.

9. AFRODAD (2002). Fair And Transparent Arbitration on Debt, Issues Paper No. 1/2002.

10. UNECA, The African Ministers of Finance meeting in Addis Ababa, May 1999, May and June 2003.

11. MAP (2001). Capital Flows Initiative.

12. IMF (2001). $100 \%$ debt cancellation? A response from the IMF and the World Bank, IMF Issue Brief.

13. www.jubileeplus.org/hipc, Jubilee Research, Tracking HIPC, p. 5.

14. www.uneca.org Statement by Mr. Rubens Ricupero, Secretary-General of UNCTAD: Review Of The African Debt Situation And Domestic Resource Mobilisation In Africa.

15. https://www.imf.org/external/np/exr/facts/hipc.htm: (downloaded 24/08/2016).

16. Sambira, J. (2015). Borrowing Responsibily: Africa's Debt challenge, Africa Renewal Journal, New York, NY 10017 USA.

17. https://www.one.org/international/issues/debt-cancellation/ (downloaded 15/09/2016).

18. Sulaiman, T. (2014). Analysis: Decade after debt relief, Africa's rush to borrow stirs concern, Reuters. 